\title{
Effectiveness of the Power Electronics Curriculum of B.E Degree Programme using Blooms Revised Taxonomy
}

\author{
Rathy G.A \\ Assistant Professor, \\ NITTTR,Chennai
}

\begin{abstract}
Curriculum includes series of planned instruction that is coordinated and articulated in a manner designed to result in the achievement by students of specific knowledge and skills and application of this knowledge. The curriculum consists of both plans for learning and the actual delivery of those plans. The Curriculum should focus on the Higher Order Thinking Skills (HOTS). A study was conducted to find out the effectiveness of the Power Electronics curriculum of B.E. Degree programme that is offered in engineering colleges of Tamilnadu. The objectives of the curriculum were classified into 13 clusters based on the category of knowledge dimension and cognitive process dimension according to Bloom's revised taxonomy of objectives. To judge the relative contribution of each cluster of objectives to the Lower order Thinking skills and the Higher order thinking skills (HOTS), Criterion Referenced Tests (CRTs) were developed for the 13 cluster of objectives of the curriculum. The study revealed that in the Power Electronics Curriculum $75 \%$ of the Lower order skills were mastered whereas only $42 \%$ of the Higher order skills were mastered. This paper suggests the three Dimensions of Power Electronics Curriculum that help the students in achieving Higher Order Thinking Skills (HOTS) as per Blooms Taxonomy.
\end{abstract}

\section{Keywords}

Cognitive dimension, Knowledge dimension, Criterion Referenced Tests(CRTs), curriculum, Higher Order Thinking Skills(HOTS), Revised Blooms Taxonomy(RBT)

\section{INTRODUCTION}

The curriculum consists of both the plans for learning and the actual delivery of those plans. Curriculum includes series of planned instruction that is coordinated and articulated in a manner designed to result in the achievement by students of specific knowledge and skills and application of this knowledge. The Curriculum should focus on the Higher Order Thinking Skills (HOTS). This study aimed at evaluating the Power Electronics Curriculum of Bachelor's Degree programme in Engineering using Blooms Revised Taxonomy.

\section{NEED FOR THE STUDY}

The Bachelor's degree programme in engineering conducted by Indian Universities is of four years duration. As the curriculum of under graduate engineering programmes consists of about 60 courses, macro level evaluation of entire programme will not provide detailed information needed for improving the curriculum of a single subject and for making it more effective. For this purpose, micro level evaluations focused on the curriculum of an individual subject have to be carried out. There is a felt need for a study to evaluate the Curriculum in the Engineering Education at the Bachelor's Degree level. As Power Electronics is a core subject for students of Electrical and Electronics Engineering, the micro level evaluation of the subject was taken up using Blooms Revised Taxonomy.

\section{REVIEW OF LITERATURE}

In formal education, a curriculum means the set of courses, and their content, offered at a school or university. The Latin word 'curriculum' refers to a 'course' or 'track' to be followed. In the context of education, where learning is the central activity, the most obvious interpretation of the word curriculum is to view it as a course or 'plan for learning' [11]. According to Melrose [6] Curriculum evaluation refers to the process by which judgment is made about the worth or merit of a curriculum or its appropriateness for the individual, the group, the organization offering it or the society within which it operates.

According to Anderson et al. [1] a curriculum unit consists of one or more educational objectives that require approximately two or three weeks to achieve. If there is more than one educational objective, the objectives are related in some way, often in that they pertain to the same topic. Interdisciplinary units and integrative units are also examples of curriculum units. Within a curriculum unit, there may be several instructional objectives, each associated with a lesson that lasts one, two, or perhaps three days. A focus on curriculum units offers four advantages over a focus on daily lessons.

1. Curriculum units provide the time needed for more integrated, holistic learning. Students can be helped to see relationships and connections among ideas, materials, activities, and topics; thus the unit structure helps them see the forests as well as the trees.

2. Curriculum units provide more flexibility in the use of available time. If a teacher runs out of time on a particular day, the activity can be carried out the next day. The availability of "flexible time" in curriculum unit is important because, activities do not always go as planned. In addition some students may need more time to learn than other students. Curriculum units allow teachers to accommodate these classroom realities.

3. Curriculum units provide a context for interpreting daily objectives, activities, and assessments.

4. The larger curriculum units provide sufficient time for instructional activities that allow for the development and assessment of student learning of more complex objectives.

An analysis of the various definitions of curriculum reveals some of the following important attributes associated with the concept of curriculum. 
Related to an occupation

Objective - oriented content

Planned learning experience

Criteria for evaluation of student's performance

3.1 Blooms Taxonomy of thinking Processes:

\subsubsection{Lower thinking skills}

1. Knowledge / Remembering

2. comprehension / Understanding

\subsubsection{Higher thinking Processes}

3. Application / Applying

4. Analysis / Analyzing

5. Synthesis / Evaluating

6. Evaluation / Creating

Benjamin Bloom has published his taxonomy of intellectual skills. The taxonomy describes the increasingly complex and abstract levels at which a concept can be understood.

\subsubsection{Remembering}

The student can remember information. The information could be specific facts, general concepts, propositions procedures and patterns. Demonstrating this level of accomplishment, students can define, identify label, list, match name, select, state etc.,

\subsubsection{Comprehension / Understanding}

The student understands the literal meaning of the material. The student can paraphrase or summarize the material give examples and explain how the example relates to the concepts. The student understands analogy and metaphor. The student can compare two entities by identifying similar and different features.

These two comprise the 'lower' thinking skills

The Higher thinking Skills (HOT: Higher Order Thinking)

\subsubsection{Application:}

The student will apply a concept to an unfamiliar situation. The student can apply engineering concepts to the uses of design and technology.

\subsubsection{Analysis:}

The student can take material and break it down into parts that are relevant to the concept. Furthermore, the student can identify the relationships between and among the parts and recognize and describe the organizational patterns.

\subsubsection{Synthesis:}

The student can collect, assemble and categorize disparate material into a coherent organized whole in a process guided by the concept, usually in concert with other associated concepts and whose final design is shaped implicitly or explicitly.

\subsubsection{Evaluation:}

The student can describe and make balanced judgments about the relevance, accuracy and importance of some material or performance from the perspective of the concept and most often associated concepts.

\subsubsection{Creativity:}

Creative thinking involves creating something new or original. It involves the skills of flexibility, originality, fluency, elaboration, brainstorming, modification, imagery, associative thinking, attribute listing, metaphorical thinking, and forced relationships. The aim of creative thinking is to stimulate curiosity and promote divergence. In talking about HOTS "higher-order thinking skills" we're concentrating on the top three levels of Bloom's Taxonomy: analysis, synthesis, and evaluation. These three skill levels are important in critical thinking

\subsection{REVIEW OF CURRICULUM EVALUATION STUDIES}

$>$ Chiang and $\mathrm{Wu}$ [3] conducted a study titled "Assessing the effectiveness of five-year mechanical engineering technology programs of junior colleges in Taiwan; An application of the CIPP evaluation model". The purpose of this study was to evaluate the mechanical engineering technology curriculum effectiveness at the junior college in Taiwan by using the CIPP evaluation model. The study concerned the areas of the curriculum, curriculum materials, individualized instruction, support services, teaching effectiveness, student achievement, and job performance. A descriptive survey method was used with questionnaires for data collection from faculty, students, graduates, and employers.

Tania [10] has conducted a study that explores an alternative approach to curriculum evaluation that pushes the boundaries, and that is responsive to social justice and equity issues in the significant area of educational activity in Australia. The syllabus evaluation was composed of four distinct components: observation, inquiry and explanation and reporting.

Kheng and Tiong [5] conducted a study titled "Curriculum reforms in a changing education system: A case of a physics curriculum package in Singapore". This framework seeks to present Physics as a body of content knowledge of high educational value in an entertaining way, besides giving a description, an analysis and an evaluation of the various components of the Physics curriculum package.

$>$ A study on "Global Engineering Education through Study -Abroad Experiences: Assessment and Lessons Learned" was conducted by Naser et al [7]. This study conducted at Kettering's University describes development and implementation of studyabroad programs for engineers and the evaluation process of these programs. It focuses not only on curriculum improvements, but factors such as how well do students adjust socially, linguistically and culturally are given equal importance

$>$ Chin [4] has conducted a study titled "Assessment of a Required Skills Course in a Sociology Curriculum". This describes a project that surveys sociology graduates about their experience with the course in the major curriculum and also effectiveness of the course.

Bhutto [2] has conducted a study on "Enhancing chemical engineering curricula in Pakistan to adapt to the new challenges of industrialization. He quotes that The London Royal Academy of Engineering, is of the strong opinion that there is a need for more basic research in engineering science but not to the detriment of engineering research. He says that engineering is evolving from a set of rather distinct disciplines (civil, thermal, electrical engineering) into a truly multi- and inter-disciplinary activity. Chemical engineers contribute increasingly in Pakistan to coal technology, polymer engineering, biochemical engineering, advanced materials, energy resources and 
environmental protection and remediation. Chemical engineers are embracing new trends while continuing their strong contributions in more traditional areas. A pedagogical shift is needed to improve programmes by placing students closer to the centre of the whole learning process.

\section{OBJECTIVES OF THE STUDY}

The Objectives of the study were

1) To determine the extent to which the objectives of the Power Electronics curriculum are achieved by the students.

2) To identify the extent to which the students have mastered the Lower order Thinking Skills and Higher order thinking skills areas of the curriculum the performance of students has to be analyzed objective -wise. Such an analysis will provide inputs to facilitate (i) learning of various topics (content areas) and (ii) attainment of the various abilities aimed by the curriculum. Bloom's revised taxonomy of objectives [1], provides a valuable frame of reference for such an analysis.

\section{METHODOLOGY OF THE STUDY}

Keeping in view the objectives, the study has been designed to evaluate the effectiveness of the Power Electronics curriculum. The study is analytical and descriptive in nature. Criterion referenced tests are more suited for assessing curriculum effectiveness than norm referenced tests. A criterion-referenced test is one that is deliberately constructed so as to yield measurements that are directly interpretable in terms of specified performance standards. The objectives of the Power Electronics Curriculum clearly state the characteristics of the stimuli and responses in the domain, which facilitates construction of test items matching the specifications of the domain. 47 Criterion Referenced Tests (CRTs), one for each of the objectives of the curriculum were developed. The number of items in each CRT ranges from 4 to 8 . These 47 CRTs consisting of a total of 210 items form a battery of CRTs in Power Electronics.

The sample for the study consisted of 296 students undergoing the fifth semester Bachelor's Degree programme in Engineering in five engineering colleges in Tamil Nadu and 24 teachers of Power Electronics (5 teachers who taught the students constituting the sample and 19 other teachers)[9].

The instruments used for the study includes a Pre test and three Post Tests in power Electronics. The Pre-Test in Power Electronics enabled an objective-wise assessment of students' performance prior to instruction. The Pre-test was an assembly of 59 items selected from the items constituting the 47 CRTs representing the 47 objectives. Each objective of the curriculum was represented in the pre-test by either one or two or four items. The post tests were administered in three sets in respectively three stages spread over one semester. Each set of post test was based on the topics covered during the period of 1 or 2 months preceding its administration.

Means, standard deviations, and reliabilities (Alpha, if item deleted) of the 31 variables included in the study are presented in Table 1.These statistics are based on a sample of 296 students.

Variable 1 to 13 represent subtests comprising CRTs under particular abilities. The 47 CRTs used in the study were classified into 13 groups depending on the ability as per Bloom's revised taxonomy (Anderson, L.W., et al., 2001) tested by each CRT. In other words the CRTs were grouped into 13 sub-tests.

Variables 14 to 17 represent performance in III Semester Mathematics and Electron Devices, IV Semester Mathematics and Electronic Circuits respectively. Using these marks means, standard deviations were calculated.

Variables 18 and 19 represent students' perception of the "Usefulness" and "Difficulty Level" of the objectives of the power Electronics curriculum. These are ratings obtained using Power Electronics Objective Student Rating Scale.

Variables 20 and 21 represent student performance in University Power Electronics Theory and Practical Examination respectively. Using these marks means, standard deviations were calculated [8].

Variables 22 to 31 represent student perceptions of ten dimensions of the Instructional Environment.

Table 1. Means, Standard Deviations and Reliability (Alpha, if item deleted) of the 31 variables included in the study. ( $=296$ Students)

\begin{tabular}{|c|c|c|c|c|}
\hline $\begin{array}{c}\text { Variable } \\
\text { No. }\end{array}$ & $\begin{array}{c}\text { Name of the } \\
\text { Variable }\end{array}$ & Mean & $\begin{array}{l}\text { Std. } \\
\text { Dev }\end{array}$ & Reliability \\
\hline 1 & $\begin{array}{l}\text { AA Knowledge } \\
\text { of terminology } \\
1.2 \text { Recalling }\end{array}$ & 2.17 & 0.77 & 0.71 \\
\hline 2 & $\begin{array}{l}\text { AB Knowledge } \\
\text { of specific } \\
\text { details and } \\
\text { elements } 1.2 \\
\text { Recalling }\end{array}$ & 3.92 & 1.29 & 0.72 \\
\hline 3 & $\begin{array}{l}\text { BA } \\
\text { Knowledge of } \\
\text { classification } \\
\text { and categories } \\
2.3 \text { Classifying }\end{array}$ & 2.30 & 1.18 & 0.73 \\
\hline 4 & $\begin{array}{l}\text { BA Knowledge } \\
\text { of classification } \\
\text { and categories } \\
2.6 \text { Comparing }\end{array}$ & 1.24 & 0.67 & 0.72 \\
\hline 5 & $\begin{array}{l}\text { BB Knowledge } \\
\text { of principles } \\
\text { and } \\
\text { generalizations } \\
2.7 \text { Explaining }\end{array}$ & 3.69 & 1.11 & 0.73 \\
\hline 6 & $\begin{array}{l}\text { BC Knowledge } \\
\text { of theories } \\
\text { models and } \\
\text { structures } 2.2 \\
\text { Exemplifying }\end{array}$ & 8.98 & 1.96 & 0.71 \\
\hline 7 & $\begin{array}{l}\text { BC Knowledge } \\
\text { of theories, } \\
\text { models and } \\
\text { structures } 2.7 \\
\text { Explaining }\end{array}$ & 1.24 & 0.66 & 0.72 \\
\hline 8 & $\begin{array}{l}\text { CA Knowledge } \\
\text { of subject } \\
\text { specific skills } \\
\text { and algorithms } \\
2.1 \text { Interpreting }\end{array}$ & 4.85 & 1.44 & 0.73 \\
\hline 9 & $\begin{array}{l}\text { CA Knowledge } \\
\text { of subject } \\
\text { specific skills } \\
\text { and algorithms } \\
2.7 \text { Explaining }\end{array}$ & 1.28 & 0.71 & 0.72 \\
\hline 10 & $\begin{array}{l}\text { CA Knowledge } \\
\text { of subject } \\
\text { specific skills } \\
\text { and algorithms } \\
\text { 3.1 Executing }\end{array}$ & 4.47 & 1.33 & 0.72 \\
\hline
\end{tabular}




\begin{tabular}{|c|c|c|c|c|}
\hline 11 & $\begin{array}{l}\text { CC Knowledge } \\
\text { of criteria for } \\
\text { determining } \\
\text { when to use } \\
\text { appropriate } \\
\text { procedures } 2.2 \\
\text { Exemplifying }\end{array}$ & 1.14 & 0.73 & 0.73 \\
\hline 12 & $\begin{array}{l}\text { CC Knowledge } \\
\text { of criteria for } \\
\text { determining } \\
\text { when to use } \\
\text { appropriate } \\
\text { procedures } 2.5 \\
\text { Inferring }\end{array}$ & 0.63 & 0.48 & 0.73 \\
\hline 13 & $\begin{array}{l}\text { CC Knowledge } \\
\text { of criteria for } \\
\text { determining } \\
\text { when to use } \\
\text { appropriate } \\
\text { procedures } 3.1 \\
\text { Executing }\end{array}$ & 0.61 & 0.49 & 0.73 \\
\hline 14 & $\begin{array}{l}\text { Performance in } \\
\text { III Semester } \\
\text { Mathematics }\end{array}$ & 53.95 & 19.09 & 0.70 \\
\hline 15 & $\begin{array}{l}\text { Performance in } \\
\text { III Semester } \\
\text { Electron } \\
\text { Devices }\end{array}$ & 57.95 & 15.36 & 0.70 \\
\hline 16 & $\begin{array}{l}\text { Performance in } \\
\text { IV Semester } \\
\text { Mathematics }\end{array}$ & 64.44 & 18.06 & 0.70 \\
\hline 17 & $\begin{array}{l}\text { Performance in } \\
\text { IV Semester } \\
\text { Electronics } \\
\text { circuits }\end{array}$ & 51.48 & 14.77 & 0.70 \\
\hline 18 & $\begin{array}{l}\text { Student } \\
\text { perception of } \\
\text { "Usefulness" of } \\
\text { the objectives } \\
\text { of the Power } \\
\text { Electronics } \\
\text { Curriculum }\end{array}$ & $\begin{array}{c}106.4 \\
5\end{array}$ & 14.70 & 0.74 \\
\hline 19 & $\begin{array}{l}\text { Student } \\
\text { perception of } \\
\text { "Difficulty } \\
\text { level" of the } \\
\text { objectives of } \\
\text { the Power } \\
\text { Electronics } \\
\text { Curriculum }\end{array}$ & 75.25 & 15.54 & 0.75 \\
\hline 20 & $\begin{array}{l}\text { Performance in } \\
\text { University } \\
\text { Power } \\
\text { Electronics } \\
\text { Theory } \\
\text { Examination }\end{array}$ & 59.81 & 12.84 & 0.70 \\
\hline 21 & $\begin{array}{l}\text { Performance in } \\
\text { University } \\
\text { Power } \\
\text { Electronics } \\
\text { Practical } \\
\text { Examination }\end{array}$ & 86.84 & 11.91 & 0.71 \\
\hline 22 & $\begin{array}{l}\text { Student } \\
\text { perception } \\
\text { (IESS) of } \\
\text { Student } \\
\text { Preparedness }\end{array}$ & 46.10 & 7.05 & 0.72 \\
\hline
\end{tabular}

\begin{tabular}{|c|c|c|c|c|}
\hline 23 & $\begin{array}{l}\text { Student } \\
\text { perception } \\
\text { (IESS) of } \\
\text { Adequacy of } \\
\text { Instructional } \\
\text { Time }\end{array}$ & 47.77 & 6.22 & 0.71 \\
\hline 24 & $\begin{array}{l}\text { Student } \\
\text { perception } \\
\text { (IESS) of } \\
\text { Teacher } \\
\text { Preparedness }\end{array}$ & 101.37 & 13.49 & 0.70 \\
\hline 25 & $\begin{array}{l}\text { Student } \\
\text { perception } \\
\text { (IESS) of } \\
\text { Instructional } \\
\text { Resources }\end{array}$ & 93.07 & 10.50 & 0.71 \\
\hline 26 & $\begin{array}{l}\text { Student } \\
\text { perception } \\
\text { (IESS) of } \\
\text { Instructional } \\
\text { Methods and } \\
\text { Procedures }\end{array}$ & $\begin{array}{c}142.3 \\
6\end{array}$ & 15.96 & 0.70 \\
\hline 27 & $\begin{array}{l}\text { Student } \\
\text { perception } \\
\text { (IESS) of } \\
\text { Teacher's } \\
\text { Resourcefulnes } \\
\text { s }\end{array}$ & 92.23 & 11.44 & 0.70 \\
\hline 28 & $\begin{array}{l}\text { Student } \\
\text { perception } \\
\text { (IESS) of Task } \\
\text { Orientation of } \\
\text { the Class }\end{array}$ & 65.22 & 7.58 & 0.70 \\
\hline 29 & $\begin{array}{l}\text { Student } \\
\text { perception } \\
\text { (IESS) of } \\
\text { Order and } \\
\text { Organization of } \\
\text { Class }\end{array}$ & 96.91 & 10.89 & 0.70 \\
\hline 30 & $\begin{array}{l}\text { Student } \\
\text { perception } \\
\text { (IESS) of } \\
\text { Evaluation } \\
\text { Procedures } \\
\text { Used }\end{array}$ & 65.14 & 8.47 & 0.71 \\
\hline 31 & $\begin{array}{l}\text { Student } \\
\text { perception } \\
\text { (IESS) of } \\
\text { Feedback } \\
\text { Provided to } \\
\text { Students }\end{array}$ & 47.15 & 7.20 & 0.70 \\
\hline
\end{tabular}

\section{FINDINGS OF THE STUDY}

Findings of this study will be discussed in this section.

\subsection{Percentage of Students Mastering each Subject}

The scores obtained by individual students in each of the CRTs in the battery were summed to get the total score on CRTs. Figure 1 shows the distribution of total scores of 296 students on the battery of CRTs in Power Electronics. The maximum possible score on the battery of CRTs was 210 . 
The frequency distribution of total scores of 296 students on the battery of CRTs in power electronics curriculum is presented in Table 2.

Table 2

Frequency Distribution of Total Scores of 296 Students on the Battery of CRTs in Power Electronics

\begin{tabular}{|c|c|c|}
\hline Class Interval & Mid Point & Frequency \\
\hline $161-170$ & 165.5 & 0 \\
\hline $151-160$ & 155.5 & 1 \\
\hline $141-150$ & 145.5 & 12 \\
\hline $131-140$ & 135.5 & 23 \\
\hline $121-130$ & 125.5 & 52 \\
\hline $111-120$ & 115.5 & 55 \\
\hline $101-110$ & 105.5 & 51 \\
\hline $91-100$ & 95.5 & 44 \\
\hline $81-90$ & 85.5 & 30 \\
\hline $71-80$ & 75.5 & 13 \\
\hline $61-70$ & 65.5 & 14 \\
\hline $51-60$ & 55.5 & 4 \\
\hline $41-50$ & 45.5 & 1 \\
\hline $31-40$ & 35.5 & 0 \\
\hline
\end{tabular}

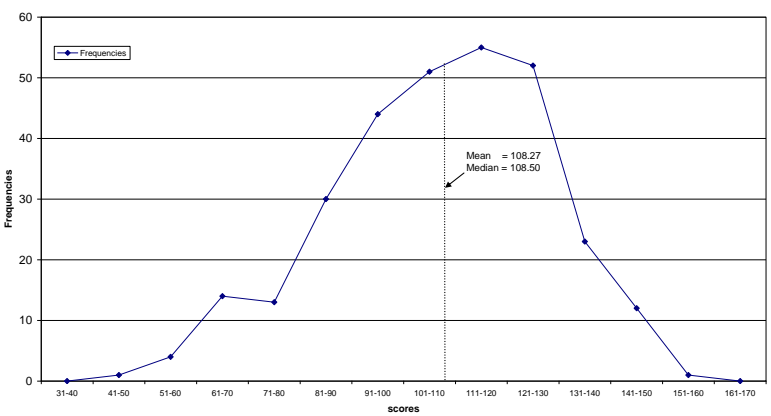

Fig 1 Frequency polygon depicting the distribution of total scores of 296 students on the battery of CRTs in Power Electronics

For CRTs having four items in each a cut off score of 3 (an equivalent of 75\%) was fixed as the criterion level (mastery level) for classification of students as masters. For CRTs having six items in each the mastery criterion was fixed at 4 (an equivalent of $66.66 \%$ ). For CRTs having eight items in each the mastery criterion was fixed at 5 (an equivalent of $62.50 \%$ ).

An objective which has been mastered by at least $51 \%$ of the students is considered as a mastered objective. On applying the above criterion it was found that 24 out of 47 objectives have been mastered by the students. This implies that about $51 \%$ of the objectives of the curriculum are effective in the sense that they have been mastered by the students.

\section{CONCLUSION}

On the basis of the findings of the research study the following conclusions were arrived at (i) $77.78 \%$ of the objectives of the curriculum representing the lower order thinking skills viz., Factual Knowledge and Remember have been mastered by the students.

(ii) Only $45.16 \%$ and $42.86 \%$ of the objectives representing higher order Thinking skills viz., Conceptual; and Procedural Knowledge have been mastered by students.

iii) Only $51 \%$ of the objectives of the Power Electronics curriculum were effective in the sense that they have been mastered by the students. In particular achievement of objectives representing higher order abilities is not satisfactory.

\section{REFERENCES}

[1] Anderson and Krathwohl, 2001. A Taxonomy for Learning, Teaching and Assessing: A Revision of Bloom's Taxonomy of Educational Objectives, Abridged Edition: Addision Wesley Longman, USA.

[2] Bhutto, 2005. Enhancing chemical engineering curricula in Pakistan to adapt to the new challenges of industrialization Published in the journal world transactions on engineering and technology education 2005, Vol. 4, No. 2, pages 239244 .

[3] Chiang and $\mathrm{Wu}, 1996$. Assessing the effectiveness of fiveyear mechanical engineering technology programs of junior colleges in Taiwan, R.O.C.: An application of the CIPP evaluation model. United States -- Florida ProQuest document.

[4] Chin, J. 2005. Assessment of a Required Skills Course in a Sociology Curriculum, Paper presented at the annual meeting of the American Sociological Association, Marriott Hotel, Philadelphia.

[5] Kheng and Tiong. 2001. Curriculum reforms in a changing education system: A case of a physics curriculum package in Singapore. In The Australian Association for Research in Education (AARE)(2001) Conference abstracts, Compiler and Editor: Peter L. Jeffery.

[6] Melrose, M. 1996. Encouraging Transactional and critical models of curriculum evaluation. Different approaches: Theory and practice in higher education. Proceedings HERDSA Conference, Perth, Australia.

[7] Naser, et al. 2002. Global Engineering Education through Study-Abroad Experiences: Assessment and Lessons Learned and published in Proceedings of the 2002 ASEE/ SEFI/TUB Colloquium., American Society for Engineering Education.

[8] Nitko, A.J. 1983. Educational Tests and Measurement - An Introduction, New York: Harcourt Brace Jovanovich

[9] Rathy, G.A. 2009. Effectiveness of Implementation of Power Electronics Curriculum in Engineering Colleges of Tamil Nadu. Unpublished doctoral dissertation, Madras University.

[10] Tania, 2001. Developing community in constructing professional knowledge as a means of informing policy about social justice and equity in the curriculum. In The Australian Association for Research in Education (AARE) (2001) Conference abstracts, Compiler and Editor: Peter L. Jeffery.

[11] Taba, H. 1962. Curriculum Development: Theory and Practice. New York: Harcourt Brace and World. 